\title{
EVOLUÇÃO SUPÉRGENA DAS ROCHAS CARBONATÍTICAS RICAS EM FOSFATO DO \\ COMPLEXO ALCALINO DE JUQUIÁ (SP)*
}

\author{
A.Alcover Neto ${ }^{1}$ \\ M.C.Toledo-Groke ${ }^{2}$
}

O intemperismo sobre as rochas carbonatíticas do complexo de Juquiá (SP) gerou uma jazida residual de fosfato apatitico com teores médios de $16 \%$ de $\mathrm{P}_{2} \mathrm{O}_{5}$. A rocha original é um carbonatito do tipo beforsito, que apresenta estrutura interna fluidal e ocorre de maneira contínua, expondo, no atual nivel de erosão, uma área de $2 \mathrm{~km}^{2}$ de material carbonatítico, o que não é comum nos maciços alcalinos com carbonatitos, onde estas rochas costumam ocorrer apenas como diques e veios.

A rocha primária é formada basicamente por dolomita rica em ferro e manganês e apatita (fluorhidroxiapatita). Magnetita, barita, flogopita e clorita são acessórios, podendo chegar a $5 \%$ do volume da rocha. Barita hidrotermal é facilmente encontrada, em veios de até $1 \mathrm{~m}$ de espessura.

A apatita primária pode chegar a $50 \%$ do volume da rocha original, sendo este 0 fator responsável pela manutenção das estruturas primárias em grande parte do manto de alteração, e ainda pelọs altos teores do minério residual.

Com o objetivo de reconstituir os mecanismos de gênese desta alterita fosfática, foram estudados perfis expostos pelos trabalhos de lavra na área, que, integrados, forneceram dados para interpretações sobre a evolução morfológica, mineralógica e química dos materiais.

Na parte isalteritica do perfil, foram identificadas quatro fácies:

1) fácies carbonatito em início de alteração;

\footnotetext{
*Apoio FAPESP e CNPq.

1Pós-graduação, Departamento de Geologia Geral, Instituto de Geociências, USP.

2Departamento de Geologia Geral, Instituto de Geociências e Núcleo de Pesquisa em Geoquímica e Geofísica da Litosfera, USP.
} 
2) fácies isalterita inicial;

3) fácies isalterita mais evoluída e

4) fácies isalterftica de transição entre carbonatito e rocha alcalina silicática.

Estas fácies, que são recobertas por niveis argiloferruginosos aloteriticos e pobres em $\mathrm{P}_{2} \mathrm{O}_{5}$, que ocorre na forma de fosfatos secundários de $\mathrm{Al}$, representam dois eventos sucessivos:

- dissolução dos carbonatos (fácies 1 e 2);

- reciclagem parcial da apatita primária com produção de apatita secundária (fácies 3).

A fácies 4 mostra, no material intemperizado, as relações primárias (eventos magmáticos, tardimagmáticos e hidrotermais) entre a rocha alcalina silicática pré-existente e o carbonatito mais recente.

As composições mineralógica e química dos materiais integradas às suas relações morfológicas permitiram considerações sobre o comportamento dinâmico dos principais elementos químicos envolvidos, ressaltando:

- iluviação intensa de $\mathrm{CO}_{3}{ }^{-2}, \mathrm{Mg}^{+2}, \mathrm{H}_{4} \mathrm{SiO}_{4}, \mathrm{SO}_{4}^{-2}, \mathrm{~K}^{+1}$;

- reciclagem no perfil de $\mathrm{PO}_{4}{ }^{-3}, \mathrm{Ca}^{+2}, \mathrm{Ba}^{+2}$ e subordinadamente $\mathrm{CO}_{3}{ }^{-2}$;

- fixação preferencial e eluviação eventual de $\mathrm{Fe}^{+3}, \mathrm{Ti}^{+4}, \mathrm{Al}^{+3} \mathrm{e} \mathrm{Mn}^{+4}$. 